\title{
THE EFFECT OF PARTICIPATION OF SCHOOL BUDGET AND ASSESSMENT ON BUDGETARY SLACK WITH MODIFIED BY COMPLIANCE WITH ACCOUNTING RULES IN THE SENIOR HIGH SCHOOL AND VOCATIONAL SCHOOLS IN THE CITY OF PALOPO, INDONESIA
}

\author{
Syamsul Kamal \\ Magister scholar, Post Graduate School of Economics \\ Hasanuddin University \\ South Sulawesi, Indonesia \\ Mediaty \\ Professor of Economics, Post Graduate School of Economics \\ Hasanuddin University \\ South Sulawesi, Indonesia \\ Sanusi Fattah \\ Ph.D of Economics, Post Graduate School of Economics \\ Hasanuddin University \\ South Sulawesi, Indonesia \\ DOI: $10.31364 /$ SCIRJ/v7.i7.2019.P0719678 \\ http://dx.doi.org/10.31364/SCIRJ/v7.i7.2019.P0719678
}

\begin{abstract}
This study aims to analyze (i) the effect of participation of school budget and assessment on budgetary slack; and (ii) the effect of participation of school budget and assessment on budgetary slack by considering compliance with accounting rules as a moderating variable. Quantitative approaches are used to test and analyze the factors that influence budgetary slack. Research location in Palopo City, South Sulawesi Province. The research schedule is carried out in one semester. The population in this study were all members of the senior high school or vocational school budgeting team in Palopo City as many as 138 people. Withdrawal the number of samples in this study using saturated sampling. Data collection techniques using a questionnaire. The measurement scale used is a Likert scale with five components. Data analysis techniques in this study used regression analysis with the Moderating Regression Analysis (MRA) method. The results showed that participation of school budget and assessment had a negative and significant effect on budgetary slack, so the first hypothesis was rejected. Compliance with accounting rules moderates (positive influence of participation of school budget and assessment on budgetary slack), thus the second hypothesis is accepted.
\end{abstract}

Index Terms - participation of school budget and assessment, compliance with accounting rules, budgetary slack, agency, school

\section{INTRODUCTION}

Participation of school budgeting and assessment as a system that can be implemented to plan, coordinate, and supervise all activities of the education manager. The phenomenon of participation of school budget and assessment has been discussed with various previous researchers such as Jack (2015) explaining that the non-optimal use of BOS funds is marked by improper closure of funds, oversight of BOS funds that are not optimal, and differences in the school budget preparation process because they are not adheres to the principle of division of authority. 
Some schools develop work plans and school budgets that are not compatible with performance-based budgeting, so that the indicators set cannot be achieved. These conditions indicate that there are still schools that have not implemented the Education Management Standards (Hariyadi, 2015). Schools are required to manage existing finances so as to prevent unplanned use in participation of school budgets and assessments. The effectiveness of financing is an important factor to prevent wasteful use of operational funds (Ferdi, 2013). Some other problems related to the management of school funds include (a) the school does not announce the amount of subsidies received, and (b) the school does not provide a report on the management of funds to the community.

Issues related to participation in school budgeting and assessment in education are crucial to be discussed in depth. Referring to previous literature and researchers, the participation of school budget and assessment factors has a strong impact on the emergence of budgetary slack. Mediaty (2010) has explained that participation of school budgeting and assessment is a process that describes the parties involved in preparing the budget, and has an impact on the budget target.

The phenomenon of the problem of the process of preparing school budgets as a strategic issue for scientific research, because these problems are related to school planning both short and long term. The problem that often arises is the case of corruption of misuse of school finances for personal or group interests. School policies that are different from planning in the School Expenditure Plan are strong indicators that there are problems in preparing the budget.

Problems with the process of preparing the school budget do not only concern the interests of teachers and schools, but also related to the head of the office and even the head of the region because of certain interests. This condition is further exacerbated by the position of the principal who is difficult to supervise, because the oversight function of the school committee is very weak. This fact explains that financial management in the scope of schools is considered very low so that budgetary slack still occurs frequently.

Misuse of school budgets generally occurs in the allocation of rehabilitation funds, procurement of school infrastructure and school operations. This is due to the large amount of budget used so that there are many gaps in corruption in the budget preparation process. These problems have an impact on increasing the burden of costs that must be borne by parents of students, the next impact is a decline in the quality of educational services that are detrimental to the community.

In the process of preparing school budgets, it requires the active involvement of individuals so that individuals are motivated and have the responsibility to make maximum efforts to plan and prepare a predetermined budget. participation of school budgets and assessments will make it easier for teachers and school committee members to negotiate future budget targets. Budget participation provides an opportunity for all parties in the school to interact and communicate with their superiors (school principals or head of offices) so that the target of the school budget plan can be achieved. A successful school budget is a reflection of individual success.

Participation of school budgeting and assessment can minimize budgetary slack (Kameliawati, 2013). Such participation is very important because subordinates can help provide information about future planning, so that budget planning becomes more accurate. In general, budgetary slack occurs because bahwan submits a budget by minimizing revenue and increasing costs compared to the estimation that should be submitted. One of the main causes of the emergence of budgetary slack is budgetary participation.

Research findings of Haliah et al. (2015) that budgetary participation directly and significantly affects budgetary slack in local government work units in South Sulawesi. The tendency to create budget gaps is because of the trust in subordinates in making decisions about participatory budgeting. However, Buckland (1999) found that budgetary participation had no significant effect on budgetary slack. Sukmawati's research (2016) explains the role of accounting rule compliance variables that are proven to influence the tendency of accounting fraud. This study aims to analyze (i) the effect of participation of school budget and assessment) on budgetary slack; and (ii) the effect of participation of school budget and assessment on budgetary slack by considering compliance with accounting rules as a moderating variable.

\section{LITERATURE REVIEW}

\subsection{Participation of school budget and assessment}

Budget is a management tool in achieving goals. So the budget is not an objective and cannot replace management (Nafarin, 2000: 78). A budget is a detailed plan formally stated in quantitative, financial and non-financial measures, regarding the acquisition and use of organizational resources and accountability centers to carry out their activities within a certain timeframe, generally one year, to achieve objectives organization (Supriyono, 2005: 91).

The budgeting process is an important activity and involves various parties, both top-level managers and lower-level managers who will play a role in preparing and evaluating various alternatives to budget targets. The role of managers both bottom managers, middle managers and top managers in the preparation of the budget will provide benefits such as reducing information inequality in the company and lead to greater commitment to managers in implementing and meeting the budget. 


\subsection{Compliance with Accounting Rules}

The requirement for organizations to have instructions or guidelines used by management to determine and carry out all activities of the organization and including the rules of accounting activities. Sukmawati (2016) states that accounting rules are made as a basis for preparing financial statements. Referring to the accounting standards, there are standard rules used in the presentation and disclosure of financial statements based on the rules that have been made by the Indonesian Institute of Accountants. Accounting standards used by governments are referred to as Government Accounting Standards. Government Accounting Standards are accounting principles applied in preparing and presenting government financial reports.

Accounting rules refer to actions that must be carried out in accordance with the principles in accounting. The accounting rules have been designed in such a way as a basic guideline / guide in preparing financial reports in any organization. Accounting standards have various rules that must be obeyed in the measurement and presentation of financial statements based on certain rules. The information available in the financial statements is needed for stakeholders, investors and management, so the information must be reliable. Thus rules are needed to maintain the reliability of the information (financial statements) and avoid actions that can harm stakeholders, investors and management (Hodder \& Hopkins, 2012).

\subsection{Budgetary Slack}

Agency theory can be defined as a concept that explains the contract between one or more people who act as principals to show others as agents to perform services for the principal's interests, including delegating power in decision making (Jensen and Meckling, 1976: 316). The practice of budgetary slack in the perspective of agency theory is influenced by conflicts of interest between agents and principals that arise when each party strives to achieve or maintain the desired level of prosperity.

According to Buckland (1999) deviant behavior by creating budget gaps is caused because the main focus of the budget is resources (inputs) not on profits (output). Factors that encourage a manager (leader) to budgetary slack, namely: frequent supervisors or top-level management change or cut the proposed budget. Usually a manager sets a budget for his division by considering various factors both in terms of volume and profit, but after it is submitted to the top manager it turns out that the budget is changed without discussing with subordinates.

\section{RESEARCH METHODS}

This research was conducted to test and analyze the factors that influence budgetary slack by placing participation of school budgeting and assessment as independent variables, then the compliance with accounting rules as moderation variables. This research was conducted in Palopo City, South Sulawesi Province. The selection of research locations is based on the gap phenomenon and is supported by research gaps in vocational schools in Palopo City. This research is scheduled to be carried out in one semester from the time the research proposal is feasible to proceed. The population in this study were all members of the senior high school or vocational school budgeting team in Palopo City. The withdrawal of the sample size in this study uses saturated sampling (the entire population is sampled) and purposive sampling (the sample is determined based on certain considerations). Data analysis method in this study uses regression analysis with the Moderating Regression Analysis (MRA) method which aims to test whether the compliance with accounting rules variable moderates the effect of participation of school budget and assessment on budgetary slack 


\section{RESULTS AND DISCUSSION}

\subsection{Analysis of Research Instruments} follows.

Analysis of the research instrument consisted of validity and reliability tests. The complete test results are presented as

Table 1

Results of Analysis of Validation

\begin{tabular}{|c|c|c|c|c|c|}
\hline Variables & Indicator & $\begin{array}{c}\text { Cronbach's Alpha if } \\
\text { Item Deleted }\end{array}$ & Information & $\begin{array}{c}\text { Cronbach's } \\
\text { Alpha }\end{array}$ & Information \\
\hline \multirow{12}{*}{$\begin{array}{l}\text { Participation of } \\
\text { school budget and } \\
\text { assessment }\end{array}$} & $\mathrm{X} 1.1$ & 0,807 & Valid & \multirow{12}{*}{0.828} & \multirow{12}{*}{ Reliable } \\
\hline & $\mathrm{X} 1.2$ & 0.817 & Valid & & \\
\hline & $\mathrm{X} 1.3$ & 0.820 & Valid & & \\
\hline & X1.4 & 0.816 & Valid & & \\
\hline & $\mathrm{X} 1.5$ & 0.830 & Valid & & \\
\hline & X1.6 & 0.828 & Valid & & \\
\hline & $\mathrm{X} 1.7$ & 0.812 & Valid & & \\
\hline & $\mathrm{X} 1.8$ & 0.805 & Valid & & \\
\hline & X1.9 & 0.813 & Valid & & \\
\hline & $\mathrm{X} 1.10$ & 0.811 & Valid & & \\
\hline & $\mathrm{X} 1.11$ & 0.808 & Valid & & \\
\hline & $\mathrm{X} 1.12$ & 0.809 & Valid & & \\
\hline \multirow{8}{*}{$\begin{array}{l}\text { Compliance with } \\
\text { accounting rules }\end{array}$} & z1.1 & 0.827 & Valid & \multirow{8}{*}{0.761} & \multirow{8}{*}{ Reliable } \\
\hline & $\mathrm{z} 1.2$ & 0.730 & Valid & & \\
\hline & $\mathrm{z} 1.3$ & 0.702 & Valid & & \\
\hline & $\mathrm{z} 1.4$ & 0.708 & Valid & & \\
\hline & $\mathrm{z} 1.5$ & 0.739 & Valid & & \\
\hline & z1.6 & 0.731 & Valid & & \\
\hline & $\mathrm{z} 1.7$ & 0.719 & Valid & & \\
\hline & $\mathrm{z} 1.8$ & 0.729 & Valid & & \\
\hline \multirow{10}{*}{ Budgetary Slack } & Y1.1 & 0.838 & Valid & \multirow{10}{*}{0.851} & \multirow{10}{*}{ Reliable } \\
\hline & $\mathrm{Y} 1.2$ & 0.838 & Valid & & \\
\hline & Y1.3 & 0.839 & Valid & & \\
\hline & Y1.4 & 0.839 & Valid & & \\
\hline & Y1.5 & 0.845 & Valid & & \\
\hline & Y1.6 & 0.831 & Valid & & \\
\hline & Y1.7 & 0.826 & Valid & & \\
\hline & Y1.8 & 0.832 & Valid & & \\
\hline & Y1.9 & 0.847 & Valid & & \\
\hline & $\mathrm{Y} 1.10$ & 0.840 & Valid & & \\
\hline
\end{tabular}

Based on the results of the analysis of validity and reliability shows that the independent variable (X1), moderation variable (compliance with accounting rules), and the dependent variable (Budgetary Slack) are valid and reliable based on the construct and each indicator.

\subsection{Moderating Regression Analysis (MRA) Analysis}

Moderating Regression Analysis is part of multiple linear regression, in the regression equation contains the interaction or multiplication of two independent variables (participation in the preparation of APBS) and moderation (compliance with accounting rules) as a form of depiction of the moderating variable against the dependent variable (Budgetary Slack). The results of the Moderating Regression Analysis calculation using SPSS 20.0 software show the following results: 
Table 2

Results of Analysis

\begin{tabular}{|c|c|c|c|c|c|}
\hline \multirow[t]{2}{*}{ Variable } & \multicolumn{2}{|c|}{$\begin{array}{l}\text { Unstandardized } \\
\text { Coefficients }\end{array}$} & \multirow{2}{*}{$\begin{array}{l}\text { Standardized } \\
\text { Coefficients } \\
\text { Beta } \\
\end{array}$} & \multirow[b]{2}{*}{ T-value } & \multirow[b]{2}{*}{ Information } \\
\hline & B & Std. Error & & & \\
\hline (Constant) & 2.502 & 0.262 & & 9.563 & 0.000 \\
\hline $\begin{array}{l}\text { Participation of school } \\
\text { budget and assessment }\end{array}$ & 0.167 & 0.081 & 0.194 & 2.064 & 0.041 \\
\hline $\begin{array}{l}\text { Compliance with } \\
\text { accounting rules } \\
\text { participation of school }\end{array}$ & 0.321 & 0.079 & 0.382 & 4.074 & 0.000 \\
\hline $\begin{array}{l}\text { budget and assessment } \\
x \text { Compliance with } \\
\text { accounting rules }\end{array}$ & -0.019 & 0.009 & -0.148 & -2.047 & 0.043 \\
\hline R Square & & & 0.308 & & \\
\hline $\begin{array}{l}\text { Adjusted R Square } \\
\text { F }\end{array}$ & & & $\begin{array}{c}0.292 \\
19,850\end{array}$ & & \\
\hline F value & & & 0.000 & & \\
\hline
\end{tabular}

The results of the Moderating Regression Analysis show that the participation variable for the participation of school budget and assessment has a $\beta 1$ coefficient of 0.167 and a significance level of $p$-value of $0.041<$ from $\alpha 0.05$, so that the first Hypothesis (H1) is rejected. These results indicate that participation in participation of school budget and assessment has a positive and significant effect on budgetary slack. Table 5.10 shows that the participation of school budget and assessment and the compliance with accounting rules has a coefficient value of $\beta 1$ of -0.019 and a significance level of p-value of $0.043<$ of $\alpha 0.05$, so that the second Hypothesis (H2) is accepted.

\section{CONCLUDING REMARKS}

The participation of school budget and assessment has a positive and significant effect on budgetary slack. This condition illustrates that the higher the level of participation of school budget and assessment, the higher budgetary slack arises. The participation of school budget and assessment drafting team in making budgets often uses facilities to achieve the budget, so it has a tendency to create budgetary slack so that the budget is easily achieved. The compliance with accounting rules rules moderates (weakens) the positive influence of participation of school budget and assessment on budgetary slack. This shows that compliance with accounting rules is needed so that the participation of school budget and assessment team does not slack.

\section{REFERENCES}

[1] Buckland, C.S. (1999). The effect of budget emphasis, budget participation, trust and organizational commitment on job related tension and propensity to create slack: Empirical evidence from Norway (Master's thesis).

[2] Ferdi, W.P. (2013). Pembiayaan Pendidikan: Suatu Kajian Teoritis. Jurnal Pendidikan dan Kebudayaan, Vol. 19, No. 4.

[3] Haliah., Gagaring., Mediaty., \& Mushar. (2015). The effects of the asymmetry, thepolitical and the cultural information on the budgetary participation and budgetary slack in the local government (the studies for the development of the good governance budgeting with the wisdom local culture-based). IJABER, Vol. 13, No. 5.

[4] Hariyadi. (2015). Beberapa faktor yang mempengaruhi penyusunan anggaran pendapatan dan belanja sekolah (APBS) berbasis kinerja (Studi Empiris di SMK Negeri Se-Kota Madiun). Jurnal Akuntansi dan Pendidikan, Vol. 4, No. 1.

[5] Hodder, L.D., \& P.E. Hopkins (2012). Agency Problems, Accounting Slack and Banks' Response to Proposed Reporting of Loan Fair Values. Kelley School of Business, Indiana University.

[6] Jack, H. (2015). Optimalisasi anggaran pendapatan dan biaya sekolah: Kajian di sekolah Kota Banda Aceh. Jurnal Pencerahan, Vol. 9, No. 2. 
[7] Jensen, M.C., \& W.H. Meckling. (1976). Theory of the firm: Managerial Behavior, Agency Costs and Ownership structure. Journal of Financial Economics 3, 305-360.

[8] Kameliawati (2013). Analisis Pengaruh Partisipasi Anggaran, Informasi Asimetri, Budaya dan Komitmen Organisasi Terhadap Budgetary Slack Pada Rumah Sakit di Kabupaten Wonogiri. Fakultas Ekonomi. Universitas Muhammadiyah Surakarta.

[9] Mediaty. (2010). Pengaruh partisipasi penyusunan anggaran, dan gaya kepemimpinan terhadap kinerja aparatur Pemerintah Daerah Provinsi Sulawesi Selatan. Majalah Ekonomi, Tahun XX, No. 3.

[10] Nafarin, M. (2000). Penganggaran Perusahaan. Edisi Pertama. Salemba Empat, Jakarta.

[11] Sukmawati, A. (2016). Faktor-Faktor yang Berpengaruh Terhadap Kecenderungan Kecurangan Akuntansi Dengan Perilaku Tidak Etis Sebagai Variabel Intervening. (Studi Kasus Pada Universitas Brawijaya Malang). Tesis. Magister Akuntansi. Universitas Brawijaya.

[12] Supriyono, R.A. (2005). Pengaruh Komitmen Organisasi, Keinginan Sosial, dan Asimetri Informasi terhadap Hubungan Antara Partisipasi Penganggaran dengan Kinerja Manajer. Jurnal Ekonomi dan Bisnis Indonesia, Vol. 20, No. 1. 